\title{
Perbedaan Model Pembelajaran Guided Discovery terhadap Hasil Belajar Fisika Siswa Kelas VIII SMP Negeri 3 Sindue
}

\author{
Aniar, Marungkil Pasaribu dan Syamsu \\ e-mail: niar_aniar89@yahoo.com \\ Program Studi Pendidikan Fisika FKIP Universitas Tadulako \\ Jl. Soekarno Hatta Km. 9 Kampus Bumi Tadulako Tondo Palu - Sulawesi Tengah
}

\begin{abstract}
Abstrak - Penelitian ini bertujuan untuk menguji signifikansi perbedaan hasil belajar fisika siswa dengan model pembelajaran guided discovery pada SMP Negeri 3 Sindue. Jenis penelitian yang digunakan adalah kuasi eksperimen dengan desain "The Non Equivalen Pretest-Posttest Design".Sampel dipilih dengan menggunakan teknik purposive sampling dan menghasilkan kelas VIII C sebagai kelas eksperimen dan kelas VIII A sebagai kelas control. Instrumen yang digunakan berupa tes hasil belajar siswa dalam bentuk pilihan ganda. Berdasarkan hasil pengolahan data dari 25 skor ideal, Berdasarkan hasil pengolahan data, diperoleh rerata skor hasil belajar fisika siswa kelas eksperimen adalah 15,00 dengan standar deviasi 3,74. Untuk kelas kontrol diperoleh rerata adalah 9,60 dengan standar deviasi 3.12. dengan menggunakan teknik statistik uji-t dua pihak untuk menguji pengaruh rerata skor hasil belajar siswa dengan signifikansi $\alpha=0,05$ dan. Diperoleh nilai hasil $t_{\text {hitung }}=2,13$ dan $t_{\text {tabel }}=2,02$. Nilai ini menunjukkan bahwa nilai thitung berada diluar daerah penerimaan Ho. Dengan demikian dapat dinyatakan bahwa, terdapat perbedaan hasil belajar siswa antara kelas yang diberi perlakuan model pembelajaran guided discovery dengan kelas yang diberi perlakuan model pembelajaran konvensional.
\end{abstract}

Kata Kunci : Model Pembelajaran Guided Discovery, Hasil Belajar Fisika.

\section{PENDAHUlUAN}

Proses pembelajaran merupakan jantung dari keseluruhan proses pendidikan formal, karena melalui sebuah proses pembelajaran terjadi transfer ilmu dari guru ke siswa yang berisi berbagai tujuan pendidikan. Guru dalam pembelajaran baiknya memberikan bimbingan dan kesempatan bagi siswa untuk berkembang secara mandiri melalui penemuan yang terbimbing.

Mutu pendidikan diperoleh berdasarkan mutu pembelajaran. Dalam pembelajaran yang bermutu, siswa tidak lagi ditempatkan dalam posisi pasif sebagai penerima bahan ajaran yang diberikan guru, tetapi sebagai subyek yang aktif melakukan proses berfikir, mencari, mengolah, mengurai, menggabung, menyimpulkan dan menyelesaikan masalah. Hal ini sesuai dengan pendapat yang dikemukakan Hanafiah dan Suhana (2009) bahwa hasil pendidikan yang bermutu akan dapat tercapai melalui komponen-komponen yang bermutu, salah satunya adalah kegiatan pembelajaran bermutu ${ }^{[1]}$.

Menurut Trianto (2009) pembelajaran merupakan aspek kegiatan manusia yang kompleks, yang tidak sepenuhnya dapat dijelaskan. Dalam makna yang lebih kompleks hakikat pembelajaran adalah usaha sadar dari seorang guru untuk membelajarkan siswanya (mengarahkan interaksi siswa dengan sumber belajar lainnya) dalam rangka mencapai tujuan yang diharapkan. Sehingga dapat disimpulkan bahwa pembelajaran merupakan interaksi dua arah dari seorang guru dan siswa, dimana dalam interaksi tersebut terdapat proses yang nantinya diharapkan mampu mencapai suatu target yang telah ditetapkan sebelumnya ${ }^{[2]}$.

Sehubungan dengan pernyataan tersebut, maka diperlukan kreatifitas guru dalam mengolah dalam memilih model maupun metode pembelajaran yang tepat bagi siswa, dan dapat mengaktifkan siswa dalam setiap pembelajaran berlangsung. Salah satu alternatif model pembelajaran yang berbasis pada siswa yaitu model pembelajaran penemuan terbimbing.

Balim (2009), dalam penelitiannya yang bertujuan untuk mengidentifikasi pengaruh metode discovery terhadap prestasi akademik dan keterampilan belajar inquiry siswa, mengemukakan bahwa penggunaan metode discovery yang disusun secara konsisten memiliki efek positif terhadap peningkatan keberhasilan akademis dan keterampilan belajar inquiry siswa ${ }^{[3]}$.

Berdasarkan Penelitian yang dilakukan Nurhayati (2009) diperoleh bahwa model 
p-ISSN 2338-3240, e-ISSN 2580-5924

pembelajaran penemuan terbimbing memberikan hasil belajar yang lebih baik daripada metode konvensional karena model penemuan terbimbing menuntut peran siswa cukup besar karena pembelajaran tidak lagi berpusat pada guru tetapi pada siswa. Guru memulai kegiatan pembelajaran dengan memberikan pertanyaan yang melacak pengetahuan siswa dan mengorganisir kelas untuk kegiatan seperti pemecahan masalah, investigasi atau kegiatan lainnya. Pemecahan masalah merupakan suatu tahap yang penting dan menentukan. Ini dapat dilakukan secara individu maupun kelompok. Dengan membiasakan siswa dalam kegiatan pemecahan masalah diharapkan akan meningkatkan kemampuan siswa dalam mengerjakan persoalan fisika, karena siswa dilibatkan dalam berfikir, bereksperimen, menyelesaikan masalah dan menarik kesimpulan ${ }^{[4]}$.

Purwanto (2012), dalam penelitiannya yang bertujuan untuk mengetahui penerapan model pembelajaran guided discovery pada materi pemantulan cahaya terhadap peningkatan kemampuan berpikir kritis siswa SMP. Disimpulkan bahwa penerapan model pembelajaran guided discovery dapat meningkatkan kemampuan berpikir kritis siswa [5].

Penelitian ini mengkaji tentang perbedaan hasil belajar siswa antara kelas yang diberi perlakuan dengan model pembelajaran guided discovery dengan kelas yang diberi perlakuan model pembelajaran konvensional yang dilaksanakan di SMP Negeri 3 Sindue.

\section{METODE PENELITIAN}

Jenis penelitian ini merupakan penelitan quasi eksperimen atau quasi experimental design (eksperimen semu) ${ }^{[6]}$.

Desain penelitian eksperimen ini menggunakan the non equivalen pretest-posttest design. Desain penelitian yang digunakan dapat dilukiskan seperti pada Tabel 1.

Tabel 1 :Posttest-pretest only experiementel design

\begin{tabular}{lccc} 
Kelompok & Pre-test & treatmen & Post-test \\
\hline Eksperimen & $\mathrm{O}$ & $\mathrm{X}$ & $\mathrm{O}$ \\
Kontrol & $\mathrm{O}$ & - & $\mathrm{O}$
\end{tabular}

Keterangan:

$\mathrm{X}$ : perlakuan dengan model pembelajaran guided discovery

O : Tes hasil belajar

Penelitian dilakukan di SMP Negeri 3 Sindue. Penelitian dilaksanakan pada bulan Maret-Mei 2015. Populasi dalam penelitian ini adalah seluruh siswa kelas VIII SMP Negeri 3 sindue tahun pelajaran 2015/2016 yang terdiri dari 3 kelas. Sampel dalam penelitian ini adalah kelas VIIIA dan VIIIC. Teknik pengumpulan sampel yang digunakan adalah purposive sampling, yaitu teknik penentuan sampel dengan pertimbangan tertentu.

Instrumen yang digunakan dalam penelitian adalah tes hasil belajar fisika. Tes tersebut digunakan untuk mengetahui perbedaan hasil belajar fisika dengan model yang diterapkan pada kelas yang menjadi sampel penelitian. Tes dibuat dalam bentuk pilihan ganda sebanyak 30 item soal. Proses analisis tes dilakukan sebanyak dua kali. Yang pertama, validitas ahli yang ditekankan pada validitas isi dan validitas konstruksi. Yang kedua, adalah uji coba tes, kemudian dilanjutkan dengan menganalisis berdasarkan validitas item, tingkat kesukaran, daya pembeda, dan reliabilitas tes.

Berdasarkan hasil validitas ahli dan uji coba tes, dari 30 item soal yang diuji cobakan pada kelas VIII SMP 3 Sindue, tidak semua soal dianggap memenuhi syarat (valid). 5 soal yang tidak valid, sehingga soal yang digunakan sebagai tes hasil belajar fisika totalnya berjumlah 25 soal.

Teknik analisis data dalam penelitian ini terlebih dulu dilakukan uji normalitas untuk mengetahui apakah data yang diperoleh berdistribusi normal atau tidak. Uji normalitas yang digunakan yaitu uji chi kuadrat. Sedangkan Pengujian hipotesis yang digunakan adalah uji t (uji dua pihak). Jenis uji statistika ini bertujuan untuk membandingkan rata-rata dua grup yang saling berpasangan.

\section{HASIL DAN PEMBAHASAN}

Data hasil belajar fisika siswa diperoleh dari hasil pretest dan posttest yang dilakukan pada kedua kelas tersebut. Adapun data hasil belajar fisika siswa dapat dilihat pada tabel 2 .

\begin{tabular}{|c|c|c|c|c|}
\hline \multirow[t]{2}{*}{ Deskripsi } & \multirow[b]{2}{*}{ Pretest } & \multicolumn{2}{|c|}{ Kelas Kontrol } & \multirow{2}{*}{$\begin{array}{l}\text { Kelas } \\
\text { Eksperimen } \\
\text { Posttest }\end{array}$} \\
\hline & & Posttest & Pretest & \\
\hline $\begin{array}{l}\text { Jumlah } \\
\text { Siswa }\end{array}$ & 20 & 20 & 20 & 20 \\
\hline $\begin{array}{l}\text { Skor } \\
\text { Maksimum }\end{array}$ & 13 & 14 & 13 & 19 \\
\hline $\begin{array}{l}\text { Skor } \\
\text { Minimum }\end{array}$ & 4 & 5 & 4 & 10 \\
\hline Skor Total & 140 & 192 & 150 & 300 \\
\hline $\begin{array}{l}\text { Skor Rata- } \\
\text { rata }\end{array}$ & 7,25 & 9,60 & 7,50 & 15,00 \\
\hline $\begin{array}{l}\text { Standar } \\
\text { Deviasi }\end{array}$ & 2,48 & 3,12 & 2,56 & 3,73 \\
\hline
\end{tabular}


Dari tabel 2 dilihat bahwa terdapat perbedaan nilai pada kelas kontrol yang menggunakan model pembelajaran langsung dan model pembelajaran guided discovery.

Pengujian normalitas data penelitian ini menggunakan Chi-kuadrat dengan kriteria penerimaan $\chi^{2}$ hitung $<\chi^{2}$ tabel, taraf signifikan $=$ 0,05 , dan derajat kebebasan $\mathrm{dk}=\mathrm{k}-3$. Data yang diuji meliputi tes awal dan tes akhir hasil belajar baik kelas eksperimen maupun kelas kontrol. Hasil uji normalitas tes awal dan tes akhir dari kelas eksperimen dan kelas kontrol dapat dilihat pada Tabel 3.

Tabel 3 : Hasil Uji Normalitas Tes Awal dan Tes Akhir Kelas Eksperimen dan Kelas Kontrol

\begin{tabular}{|lcccc|}
\hline Uraian & \multicolumn{2}{c|}{ Tes Awal } & \multicolumn{2}{c|}{ Tes Akhir } \\
\hline Kontrol & Eksperimen & Kontrol & Eksperimen & \\
$\begin{array}{l}\text { Sampel } \\
\chi^{2} \text { hitung }\end{array}$ & 20 & 20 & 20 & 20 \\
$\chi^{2}$ tabel & 2,48 & 1,91 & 3,61 & 2,43 \\
Ket & \multicolumn{2}{c}{7,81} & \multicolumn{2}{c}{7,81} \\
Normal & \multicolumn{2}{c}{ Normal } \\
\hline
\end{tabular}

Berdasarkan uji normalitas pada Tabel 3 dengan menggunakan Chi-kuadrat dengan kriteria penerimaan $\chi^{2}$ hitung $<\chi^{2}$ tabel, dimana untuk tes awal baik kelas eksperimen maupun kelas kontrol nilai $\chi^{2}$ hitung lebih kecil daripada nilai $\chi^{2}$ tabel Begitupula untuk tes akhir, nilai $\chi^{2}$ hitung lebih kecil daripada nilai $\chi^{2}$ tabel, baik di kelas eksperimen maupun kelas kontrol. Artinya, data tes awal dan tes akhir baik di kelas eksperimen maupun kelas kontrol terdistribusi normal.

Pengujian homogenitas data menggunakan uji-F dengan kriteria jika $\mathrm{F}_{\text {hitung }}<\mathrm{F}_{\text {tabel }}$ maka data homogen. Hasil uji homogenitas dari kelas eksperimen dan kelas kontrol dapat dilihat pada Tabel 4.

Tabel 4. Hasil Uji Homogenitas Tes Awal dan Tes Akhir

\begin{tabular}{|lccc|}
\hline Uraian & Tes awal & Tes Akhir & Ket \\
Fhitung & 0,89 & 1,73 & \\
& & & Homogen \\
Ftabel & 2,12 & 2,12 & \\
\hline
\end{tabular}

Berdasarkan Tabel 4, nilai Fhitung<Ftabel. Hal ini menunjukkan bahwa data tersebut memiliki varians yang sama (homogen).

Pengujian hipotesis ini menggunakan statistik parametrik uji-t (uji dua pihak). Data hasil pengujian statistik tes awal dan tes akhir dapat dilihat pada Tabel 5 dan Tabel 6.
p-ISSN 2338-3240, e-ISSN 2580-5924

Tabel 5 : Uji Perbedaan Rata - Rata Kelas Eksperimen dan

\begin{tabular}{|lcccc|}
\hline \multicolumn{4}{c}{ Kelas Kontrol(pretest) } \\
\hline Kelas & $\overline{\boldsymbol{x}}$ & thitung & ttabel & Keputusan \\
\hline ksperimen & 7,50 & 0,12 & 2,02 & \\
Kontrol & 7,25 & & Ho diterima \\
\hline
\end{tabular}

Tabel 6 : Uji Perbedaan Rata - Rata Kelas Eksperimen dan Kelas Kontrol(posttest)

\begin{tabular}{|lcccc|}
\hline Kelas & $\overline{\boldsymbol{x}}$ & $\mathbf{t}_{\text {hitung }}$ & $\mathbf{t}_{\text {tabel }}$ & Keputusan \\
\hline ksperimen & 15,00 & 2,13 & 2,02 & \\
& & & & $\mathrm{H}_{1}$ diterima \\
Kontrol & 9,60 & & & \\
\hline
\end{tabular}

Berdasarkan Tabel 6 Nilai thitung $>$ ttabel atau $3,08>2,00$. Hal ini menunjukkan bahwa $t_{\text {hitung }}$ berada diluar daerah penerimaan $\mathrm{Ho}$.

Penelitian ini bertujuan untuk menguji signifikansi perbedaan hasil belajar siswa dengan menggunakan model pembelajaran guided discovery pada kelas VIII SMP Negeri 3 Sindue pada materi bunyi anatara kelas eksperimen dan kelas kontrol. Pada penelitian ini kegiatan pembelajaran dilakukan sebanyak 7 kali pertemuan, 2 kali pertemuan untuk pemberian pretest dan posttest dan 5 kali pertemuan untuk tatap muka masing-masing pada kelas eksperimen maupun pada kelas kontrol. Tes awal (pretest) yang diberikan bertujuan untuk mengetahui kemampuan awal siswa dikedua kelas, yang selanjutnya digunakan untuk menentukan kelompok dan juga sebagai data analisis penelitian. Sedangkan tes akhir (posttest) diberikan untuk mengetahui kemampuan akhir siswa di kedua kelas dan sebagai data analisis penelitian yang selanjutnya digunakan sebagai pembanding untuk melihat apakah terdapat pengaruhhasilbelajar antara kedua kelas tersebut terkait hasil belajar pada materi bunyi.

Berdasarkan analisis kuantitatif, kemampuan awal siswa dari pemberian tes awal (pretest) diperoleh skor rata-rata dari masing-masing kelas adalah 7,50 dengar standar deviasi 2,56 untuk kelas eksperimen dan 7,25 dengan standar deviasi 2,48 untuk kelas kontrol. Hasil ini menunjukkan adanaya perbedaan skor antara kedua kelas, dimana terlihat skor untuk kelas eksperimen lebih tinggi dibandingkan kelas kontrol. Hal ini yang kemudian menjadi salah satu alasan pendukung kedua kelas ini memenuhi syarat untuk dijadikan sampel.

Selanjutnya, Untuk kemampuan siswa dari pemberian tes akhir (posttest) diperoleh nilai ratarata dari masing-masing kelas adalah 15,00 dengan standar deviasi 3,73 untuk kelas eksperimen dan 9,60 dengan standar deviasi 3,12 untuk kelas kontrol. Berdasarkan data yang diperoleh tersebut, kemudian dilakukan analisis terhadap normalitas serta homogenitas varians. Hasilnya baik data pretes maupun posttest keduanya berdistribusi normal danmemilikivarians yang homogen.

Berdasarkan analisis kuantitatif data posttest diketahui,nilai rata-rata kelas eksperimen lebih besar dibandingkan dengan nilai rata-rata kelas kontrol Perbedaan antara rerata skor posttest kelas 


\section{KESIMPULAN} tersebut. Pengaruh yang signifikan terjadi pada kelas eksperimen. Dimana kelas eksperimen menggunakan model guided discovery pada model pembelajarannya sedangkan kelas kontrol menggunakan model konvensional. Setelah dilakukan uji normalitas dan homogenitas varians, selanjutnya dilakukan uji hipotesis dengan menggunakan uji-t dua pihak berdasarkan hasil skor pretest dan skor posttest. Berdasarkan hasil skor pretest dimana kedua kelas belum diberikan perlakuan, diperoleh nilai $t_{\text {hitung }}=0,12$ dan nilai tabel $=2,02$. Dengan menggunakan kriteria penerimaandimana $-\mathrm{t}_{(1-0,5 \mathrm{a})}<\mathrm{t}<\mathrm{t}_{(1-0,5 \mathrm{a})}$ diketahui $\mathrm{H}_{0}$ diterima dan hipotesis satu $\left(\mathrm{H}_{1}\right)$ ditolak. Artinya sebelum diberikan perlakuan berupa pemberian model pada proses pembelajaran, tidak terdapat hasil belajar antara kedua kelas baik kelas eksperimen maupun kelas kontrol.Selanjutnya dengan menggunakan rata-rata skor posttest dimana pada masing-masing kelas telah diberi perlakuan, diperoleh nilai $t_{\text {hitung }}=2,13$ dan nilai $t_{\text {tabel }}=2,02$. Dengan menggunakan kriteria penerimaan $\mathrm{H}_{0}$ dimana $-\mathrm{t}_{(1-0,5 \mathrm{a})}<\mathrm{t}<\mathrm{t}_{(1-0,5 a)}$, diketahui hipotesis $\mathrm{H}_{0}$ tidak terpenuhi atau ditolak dan hipotesis satu $\left(\mathrm{H}_{1}\right)$ diterima. Artinya terdapat perbedaan hasil belajar antara kelas yang mendapatkan pembelajaran menggunakan model guided discovery dengan kelas yang mendapatkan pembelajaaran menggunakan metode konvensional.

Terjadinya perbedaan hasil belajar terutama pada kelas eksperimen, tidak terlepas dari pengaruh model yang digunakan pada proses pembelajarannya yaitu model guided discovery. Dimana pada model ini siswa dituntut untuk lebihaktif dan terlibat langsung dalam proses pembelajaran pada setiap pertemuan.

Model pembelajaran guided discovery merupakan suatu model yang mengatur proses pembelajaran sedemikian rupa agar siswa memperoleh pengetahuannya bukan melalui pemberitahuan, sebagian atau seluruhnya mereka temukan sendiri. Dengan menerapkan model pembelajaran guided discovery

Hasil belajar fisika materi bunyi siswa yang diajar dengan menggunakan model pembelajaran guided discovery lebih baik daripada peserta didik yang diajar menggunakan metode konvensional. Sehingga pembelajaran fisika materi bunyi dengan menggunakan model pembelajaran guided discovery dapat dijadikan alternatif dalam pembelajaran fisika untuk meningkatkan hasil belajar siswa. Pendapat ini juga dikemukakan oleh Yulita (2012) bahwa guided discovery dapat meningkatkan hasil belajar siswa [7].

Model pembelajaran guided discovery mampu mengantarkan pesan yang disampaikan oleh guru dan dapat menjadikan siswa lebih semangat dan tertarik terhadap materi yang disampaikan oleh guru. Hal ini dikarenakan model pembelajaran penemuan terbimbing (guided discovery) yang berpusat kepada siswa (students centre) mampu membangun keaktifan dan rasa ingin tahu siswa.
Berdasarkan hasil analisis data penelitian, maka dapat ditarik kesimpulan:

1. Skor rata-rata kelas eksperimen untuk test awal (pretest) adalah 7,50 dan untuk test akhir (posttest) adalah 15,00.

2. Skor rata-rata kelas kontrol untuk test awal (pretest) adalah 7,25 dan untuk test akhir (posttest) adalah 9,60.

3. Terdapat perbedaan hasil belajar siswa antara kelas yang diberi perlakuan model pembelajaran guided discovery dengan kelas yang diberi perlakuan model pembelajaran konvensional di SMP Negeri 3 Sindue. Hal ini dapat diketahui dari hasil perhitungan pengujian hipotesis dengan menggunakan uji-t dua pihak pada posttest, dengan menggunakan rata-rata skor diperoleh $t_{\text {hitung }}=2,13$ dan $t_{\text {tabel }}=2,02$. Berdasarkan data tersebut, kriteria penerimaan $\mathrm{H}_{0}$ dimana - $\mathrm{t}$ (1 $0,5 \mathrm{a})<\mathrm{t}<\mathrm{t}_{(1-0,5 \mathrm{a})}$ tidak terpenuhi, $\mathrm{H}_{0}$ ditolak dan hipotesis satu $\left(\mathrm{H}_{1}\right)$ diterima pada taraf nyata $5 \%$ dan $\mathrm{dk}=38$.

\section{DAFTAR PUSTAKA}

[1] Hanafiah, N dan Suhana, C. 2009. Konsep Strategi Pembelajaran.Bandung : PT Refika Aditama.

[2] Trianto 2009. Mendesain Model Pembelajaran Inovatif-Progresif. Jakarta: Kencana Prenada Media Group

[3] Balim, A. G. (2009). "The Effects of Discovery Learning on Students' Success and Inquiry Learning Skills". Egitim ArastirmalariEurasian Journal of Educational Research.

[4] Nurhayati, L. 2009. Pengaruh Penggunaan Model Pembelajaran Guided Disccovery Terhadap Hasil Belajar Fisika Materi Pokok Zat dan Wujudnya Kelas VII di MTS N Pamotan Rembang. Skripsi pada Fakultas Tarbiayah Institut Agama Islam Negeri Walisongo Semarang: diterbitkan

[5] Purwanto,C.R. 2012. Penerapan Model Pembelajaran Guided Discovery pada Materi Pemantulan Cahaya untuk Meningkatkan Berpikir Kritis. [online]. Tersedia http://journal.unnes.ac.id/sju/index.php/upej [30 Januari 2015]

[6] Sugiyono, 2011. Metode penelitian Kuantitatif kualitatif dan R\&D. Bandung:Alfabeta. 
Jurnal Pendidikan Fisika Tadulako Online (JPFT)

Vol. 5 No. 1

[7] Yulita, N. 2012. Penerapan Metode Penemuan p-ISSN 2338-3240, e-ISSN 2580-5924 Terbimbing Berbantuan Lembar Kerja Siswa (LKS) Untuk Meningkatkan Aktivitas dan Hasil Belajar Siswa Kelas VII SMP Negeri 11 Kota Bengkulu.Skripsi. Bengkulu : Fakultas KIP Universitas Bengkulu. 